Techniques \& Culture

$10 \mid 1988$

D'autres idées pour observer

\title{
La classification des techniques
}

\section{Henri Clavier}

\section{OpenEdition}

Journals

Édition électronique

URL : https://journals.openedition.org/tc/848

DOI : $10.4000 /$ tc. 848

ISSN : 1952-420X

\section{Éditeur}

Éditions de l'EHESS

\section{Édition imprimée}

Date de publication : 1 mars 1988

ISSN : 0248-6016

\section{Référence électronique}

Henri Clavier, «La classification des techniques», Techniques \& Culture [En ligne], 10 | 1988, mis en ligne le 23 janvier 2006, consulté le 29 septembre 2022. URL : http://journals.openedition.org/tc/848 ; DOl : https://doi.org/10.4000/tc.848

Ce document a été généré automatiquement le 29 septembre 2022

Tous droits réservés 


\section{La classification des techniques}

Henri Clavier 